\title{
Zasady korzystania przez komisję śledczą $z$ uprawnień wynikających z art. 14 ust. 1 ustawy o sejmowej komisji śledczej ${ }^{1}$
}

The use by an investigative committee of powers arising from Article 14 para. 1 of the Act on Sejm Investigative Committees: Exercising by a committee of legally determined methods of obtaining "evidence" does not result in the possibility of perceiving of entities and people to whom commission requests are addressed as subjects of a parliamentary inquiry. However the investigative committee is bound by the scope of a resolution on its appointment, and it is allowed to exercise its rights resulting from the act only to the extent which is necessary to investigate the matter being the subject of its inquiry and in such a way that does not to infringe personal rights of third parties. The fact that the scope of activities of the investigative committee does not include an examination of activities of certain institutions does not exclude the possibility for the committee to obtain, according to provisions of the act, information and documents from such entities.

Keywords: investigative committee

Słowa kluczowe: komisja śledcza

Ekspert ds. legislacji BAS - wojciech.sypniewski@sejm.gov.pl • https://orcid.org/0000-0002-7704-5042

\section{Przedmiot opinii}

Przedmiotem opinii jest odpowiedź na pytanie: „czy Komisja śledcza do zbadania prawidłowości i legalności oraz występowania zaniedbań i zaniechań organów i instytucji publicznych w zakresie zapewnienia dochodów Skarbu Państwa z tytułu podatków od towarów i usług i podatku akcyzowego w okresie od grudnia

$1 \quad$ Opinia prawna $w$ sprawie zasad korzystania przez komisjé śledcza z uprawnień wynikających $z$ art. 14 ust. 1 ustawy o sejmowej komisji śledczej sporządzona 18 września 2018 r. na zlecenie przewodniczącego Komisji śledczej do zbadania prawidłowości i legalności oraz występowania zaniedbań i zaniechań organów i instytucji publicznych w zakresie zapewnienia dochodów Skarbu Państwa z tytułu podatków od towarów i usług i podatku akcyzowego w okresie od grudnia 2007 r. do listopada 2015 r.; BAS-WAKiU 2182/18. 
2007 r. do listopada 2015 r. może występować do Komisji Nadzoru Finansowego, Instytutu Pamięci Narodowej - Komisji Ścigania Zbrodni Przeciwko Narodowi Polskiemu i Urzędu Ochrony Konkurencji i Konsumentów, czyli instytucji, które nie zostały wskazane w uchwale o powołaniu komisji śledczej, w trybie art. 14 ust. 1 ustawy z 21 stycznia 1999 r. o sejmowej komisji śledczej?”. Istota zagadnienia sprowadza się do ustalenia relacji pomiędzy zakresem działania komisji śledczej a uprawnieniami, które przysługują komisji w celu zbadania sprawy, która została jej powierzona przez Sejm. W szczególności chodzi o rozstrzygnięcie, czy adresatem wystąpień komisji na podstawie art. 14 ust. 1 ustawy o sejmowej komisji śledczej mogą być wyłącznie podmioty objęte jej zakresem działania?

\section{Dostęp komisji śledczej do dokumentów pozostających w dyspozycji innych podmiotów}

Zgodnie z art. 14 ust. 1 ustawy o sejmowej komisji śledczej (Dz.U. 2016, poz. 1024; dalej: u.s.k.): organy władzy publicznej oraz organy innych osób prawnych i jednostek organizacyjnych nie mających osobowości prawnej, na żadanie komisji, składaja pisemne wyjaśnienia lub przedstawiaja dokumenty będace $w$ ich dyspozycji albo akta każdej sprawy przez nie prowadzonej. Cytowany przepis stanowi podstawę uprawnienia komisji, które, obok kompetencji do przesłuchiwania świadków (art. 11 u.s.k.) oraz możliwości zlecania Prokuratorowi Generalnemu przeprowadzenia określonych czynności (art. 15 u.s.k.), służy pozyskiwaniu przez komisję śledczą informacji niezbędnych dla zbadania powierzonej sprawy. Adresatem żądania komisji mogą być zarówno organy władzy publicznej, organy osób prawnych, jak również jednostki organizacyjne nieposiadające osobowości prawnej. Obowiązki, o których mowa w art. 14 ust. 1 u.s.k., ciążą na wszystkich podmiotach prawa publicznego i prawa prywatnego z wyłączeniem osób fizycznych.

Ustawa nie precyzuje zakresu „pisemnych wyjaśnień”, których domagać się może komisja, podobnie jak nie określa charakteru dokumentów, które mogą być przedmiotem takiego żądania. Ogólny charakter omawianej kompetencji najpełniej wyraża sformułowanie, które wskazuje, iż komisja może żądać akt „każdej sprawy” prowadzonej przez podmiot, do którego skierowane zostało żądanie komisji. Dostęp do informacji posiadanych przez organy władzy publicznej oraz inne podmioty prawa ma zatem charakter bardzo szeroki. Treść art. 14 ust. 1 u.s.k. wskazuje, iż chodzi o wszelkiego rodzaju dokumenty i akta, które mogą być niezbędne dla wyjaśnienia sprawy badanej przez komisję. Prawo żądania „pisemnych wyjaśnień”, obok dostępu do dokumentów i akt sprawy, gwarantuje komisji dostęp do wszelkich informacji posiadanych przez podmioty, o których mowa $\mathrm{w}$ art. 14 ust. 1. Kompetencja do żądania „wyjaśnień” z pewnością nie oznacza prawa do domagania się przez komisję opracowań, których sporządzenie wiąza- 
łoby się z wytworzeniem nowych informacji przez zobowiązanego. Przedmiotem pisemnych wyjaśnień mogą być jednak te informacje, które są w posiadaniu adresata żądania, a które nie są zawarte w dokumentach (lub aktach). Forma pisemnych wyjaśnień służyć może również przedstawieniu tych informacji, które, choć zostały utrwalone w dokumentach pozostających w dyspozycji adresata żądania, to jednak ze względów praktycznych łatwiej mogą zostać przekazane w piśmie sporządzonym specjalnie na potrzeby komisji. Z sytuacją taką będziemy mieli do czynienia w przypadku, gdy przedmiotem zainteresowania komisji będą np. określone informacje (dane) zawarte w obszernej dokumentacji finansowej (np. wysokość obrotów przedsiębiorstwa, liczba zatrudnionych pracowników). W takim wypadku względy praktyczne przemawiać mogą za tym, by komisja domagała się przedstawienia konkretnej informacji na piśmie, zamiast zapoznawać się z obszernymi dokumentami.

Komisja śledcza zachowuje swobodę w zakresie doboru środków dowodowych. Działania komisji powinny jednak respektować ograniczenia wynikające $\mathrm{z}$ art. 7 u.s.k., tzn. komisja związana jest zakresem przedmiotowym określonym w uchwale o jej powołaniu (ust. 1), a z uprawnień wynikających z przepisów ustawy może korzystać tylko w zakresie niezbędnym do wyjaśnienia sprawy będącej przedmiotem jej działania oraz w taki sposób, aby nie naruszyć dóbr osobistych osób trzecich (ust. 2). W dorobku analitycznym BAS wielokrotnie wskazywano na konieczność odróżniania od siebie dwóch odrębnych kwestii: właściwości przedmiotowej komisji śledczej (zakresu działania), potocznie utożsamianego z celem działania komisji („zbadanie określonej sprawy”) oraz zagadnienia o innym charakterze - „środków dowodowych”, które - obok art. 14 ust. 1 u.s.k. - służyć mają jego realizacji. Wskazywano, że: niedostrzeganie odrębności obu zagadnień - mimo ich związku funkcjonalnego - może prowadzić do chybionej argumentacji co do „dopuszczalności” ządań komisji śledczej².

Należy podkreślić, że korzystanie przez komisję z określonych prawem form pozyskiwania „dowodów” nie powoduje, że podmioty i osoby, względem których adresowane są żądania komisji, stają się przedmiotem śledztwa sejmowego. Stanowisko przeciwne musiałoby prowadzić do wniosku, że komisja śledcza nie może odbierać zeznań od osób prywatnych, bowiem byłoby to równoznaczne z „włączeniem” tych osób w zakres śledztwa sejmowego. Należy w tym miejscu podkreślić, że każda osoba wezwana przez komisję do złożenia zeznań, niezależnie od pełnionych funkcji, staje przed komisją jako świadek (osoba fizyczna) posiadający informacje istotne dla zbadania powierzonej przez Sejm sprawy. Tak jak przesłuchanie świadka nie „włącza” go w zakres prowadzonego śledztwa sejmowego, tak i wystąpienie w trybie art. 14 ust. 1 u.s.k. do określonego pod-

2 Zamiast wielu zob. A. Szmyt, Opinia prawna w sprawie udostępniania komisji śledczej Sejmu informacji z zasobów Instytutu Pamięci Narodowej, opinia BAS 127/05 z 17 stycznia 2005 r., niepubl. 
miotu z żądaniem przedstawienia określonych informacji nie powoduje, że adresat takiego żądania staje się przedmiotem prowadzonych przez komisję działań kontrolnych. W konsekwencji okoliczność, że zakres działania komisji śledczej nie obejmuje zbadania działalności określonych instytucji, nie wyłącza możliwości pozyskiwania przez komisję od tych podmiotów informacji i dokumentów w trybie art. 14 ust. 1 u.s.k. (w szczególności od Komisji Nadzoru Finansowego, Instytutu Pamięci Narodowej czy Urzędu Ochrony Konkurencji i Konsumentów). Pamiętać zarazem należy, że warunkiem dopuszczalności zastosowania poszczególnych instrumentów prawnych przez komisję jest konieczny związek pomiędzy pozyskiwaną informacją a przedmiotem śledztwa sejmowego.

\section{Podsumowanie}

Korzystanie przez sejmową komisję śledczą z określonych prawem form pozyskiwania „dowodów” nie powoduje, że podmioty i osoby, względem których adresowane są żądania komisji, stają się przedmiotem śledztwa sejmowego. Działania komisji powinny respektować ograniczenia wynikające z art. 7 u.s.k., tzn. komisja związana jest zakresem przedmiotowym określonym w uchwale o jej powołaniu (ust. 1), a z uprawnień wynikających z przepisów ustawy może korzystać tylko w zakresie niezbędnym do wyjaśnienia sprawy będącej przedmiotem jej działania oraz w taki sposób, aby nie naruszyć dóbr osobistych osób trzecich (ust. 2). Okoliczność, że zakres działania komisji śledczej nie obejmuje zbadania działalności określonych instytucji, nie wyłącza możliwości pozyskiwania przez komisję od tych podmiotów informacji i dokumentów w trybie art. 14 ust. 1 u.s.k. 